\title{
Over een zoete ziekte en vette jaren
}

Citation for published version (APA):

Schrauwen, P. A. J. (2011). Over een zoete ziekte en vette jaren. Maastricht University. https://doi.org/10.26481/spe.20110415ps

Document status and date:

Published: 15/04/2011

DOI:

10.26481/spe.20110415ps

Document Version:

Publisher's PDF, also known as Version of record

\section{Please check the document version of this publication:}

- A submitted manuscript is the version of the article upon submission and before peer-review. There can be important differences between the submitted version and the official published version of record.

People interested in the research are advised to contact the author for the final version of the publication, or visit the DOI to the publisher's website.

- The final author version and the galley proof are versions of the publication after peer review.

- The final published version features the final layout of the paper including the volume, issue and page numbers.

Link to publication

\footnotetext{
General rights rights.

- You may freely distribute the URL identifying the publication in the public portal. please follow below link for the End User Agreement:

www.umlib.nl/taverne-license

Take down policy

If you believe that this document breaches copyright please contact us at:

repository@maastrichtuniversity.nl

providing details and we will investigate your claim.
}

Copyright and moral rights for the publications made accessible in the public portal are retained by the authors and/or other copyright owners and it is a condition of accessing publications that users recognise and abide by the legal requirements associated with these

- Users may download and print one copy of any publication from the public portal for the purpose of private study or research.

- You may not further distribute the material or use it for any profit-making activity or commercial gain

If the publication is distributed under the terms of Article $25 \mathrm{fa}$ of the Dutch Copyright Act, indicated by the "Taverne" license above, 
Over een zoete ziekte en vette jaren 


\section{Inaugurele rede}

Mijnheer de Rector,

Zeer geachte Dames en Heren,

Vrienden en familieleden,

Ongeveer drie maanden geleden nam ik deel aan een review proces van een buitenlandse onderzoeksgroep, met als thema diabetes. Op de weg terug, op het vliegveld in Brussel zat ik een beetje moe maar voldaan stiekem mee te luisteren naar een conversatie tussen twee overduidelijke Amerikanen. Deze collega's, slank van postuur, spraken hun verbazing uit over typische Europese zaken. Op een moment in het gesprek zei een van hen "I have never been on an airport where I had to walk the entire terminal, why do they not have trains here?". Het klopt: het vliegveld van Brussel heeft inderdaad een erg lange gang van de ingang naar de terminal, en het is inderdaad zeker 5 tot 10 minuten lopen.

\section{Diabetes: een groeiend probleem}

Het wetenschapsgebied waarover mijn leerstoel verhandelt betreft de metabole - oftewel stofwisselings - aspecten van type 2 diabetes mellitus. De naam diabetes, wat letterlijk 'doorstroming' betekent, werd ongeveer 100 jaar na Christus bedacht door Aretaeus. Hij beschreef de ziekte als 'een merkwaardige aandoening die resulteert in het smelten van vlees en ledematen in urine', duidend op het feit dat zijn doodzieke patiënten overmatig urine produceerden. Later is de toevoeging 'mellitus' toegevoegd, wat in het Latijn 'zoet' betekent en wat duidt op het feit dat de urine veelal zoet is vanwege de aanwezigheid van suiker in de urine. Type 2 Diabetes Mellitus zal bij $u$ echter beter bekend zijn als suikerziekte, of zelfs ouderdomssuikerziekte. Dat laatste is weliswaar te verklaren omdat de ziekte zich vaak openbaart op hogere leeftijd. Toch is deze benaming niet meer volledig correct: tegenwoordig komt 'ouderdomssuikerziekte' op steeds jongere leeftijd voor en wordt zelfs bij jonge kinderen gediagnosticeerd. Zoals $u$ in figuur 1 kunt zien neemt het aantal patiënten met diabetes de laatste jaren zeer sterk toe (1), en komen er per jaar zo'n 70.000 nieuwe gevallen van diabetes in Nederland bij, dat is 200 nieuwe gevallen per dag. Indien dit een figuur van de beurscijfers zou zijn geweest zouden we met recht spreken over vette jaren. Helaas is deze toename in de prevalentie van diabetes iets om minder enthousiast over te zijn. 
prevalentie van diabetes in Nederland

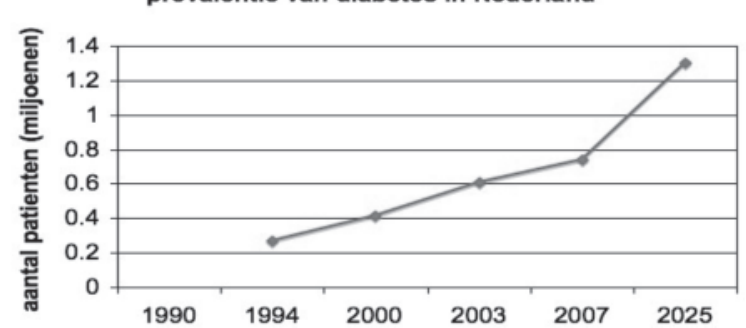

Figuur 1: prevalentie van type 2 diabetes in Nederland

\section{Hoe ontstaat diabetes?}

Het probleem bij suikerziekte is dat de patiënt niet goed in staat is om het gehalte van suiker in het bloed constant te houden. Een constant bloedsuikergehalte is echter belangrijk. Aan de ene kant zijn onze hersenen afhankelijk van suiker voor hun energiemetabolisme, en een te laag suikergehalte in het bloed kan dan ook leiden tot vermoeidheid, slapte, verminderd concentratievermogen en zelfs tot coma. Aan de andere kant is een langdurig verhoogd suikergehalte in het bloed ook schadelijk. Zoals suiker in snoep slecht is voor onze tanden en gaatjes kan veroorzaken, kan suiker in het bloed leiden tot schade aan de bloedvaten en zenuwen. Om deze twee redenen probeert het lichaam het suikergehalte binnen bepaalde grenzen constant te houden.

In 1889 verrichte de fysioloog Oskar Minkowski experimenten met honden waarbij de alvleesklier was verwijderd. Bij toeval ontdekte hij dat de urine van deze honden wel heel veel vliegen aantrok. Het gerucht gaat dat hij vervolgens deze urine proefde en merkte dat de urine mierzoet was, duidend op diabetes. Ruim 30 jaar later toonde Frederick Banting aan dat deze alvleesklier het hormoon insuline produceert. Dit hormoon, dat afgegeven wordt aan het bloed nadat we suikers hebben gegeten, zorgt ervoor dat het suiker uit het bloed opgenomen kan worden in de spieren, en dat de lever stopt met het produceren van extra suiker.

In tegenstelling tot type 1 diabetes, waarbij de patiënt vaak vanaf jonge leeftijd geen insuline kan produceren, is een type 2 diabeet vooral ongevoelig voor dit hormoon. Deze insuline ongevoeligheid - ook wel insulineresistentie genoemd - heeft tot gevolg dat het suiker onvoldoende wordt opgenomen in de spieren, waardoor het suikergehalte in het bloed zal stijgen. Op de lange duur - en dit kan tientallen jaren duren - neemt ook de insulineproductie af. Type 2 diabetes is dan ook een chronische ziekte, met een langzaam ziekteverloop maar met grote gevolgen. Een jarenlange hoge - en onbehandelde bloedsuiker kan leiden tot problemen aan de ogen, nieren, hart en botten, het verhoogt de kans op hart- en vaatziekten en verkort de levensverwachting.

Insulineresistentie ligt dus aan de basis van het ontstaan van type 2 diabetes mellitus. Het lijkt dan ook voor de hand te liggen om insulineresistentie als een ziekelijke aandoening te beschouwen, en de onderliggende pathologie te bestuderen. Toch geloof ik niet dat dat de juiste weg is. Niets is namelijk voor niets: juist ook insulineresistentie is voor ons als mens een zeer nuttig proces om te overleven.

Het is voor velen onder ons haast niet meer voor te stellen, maar er zijn tijden geweest dat de mens voor zijn eten echt moest werken. Ik wil met deze opmerking niemand beledigen, maar ik bedoel hiermee te zeggen dat de mens in vroegere tijden actief op pad moest gaan en vaak moest jagen op zijn eten. Hierbij kreeg de mens ook te maken met de veranderlijkheid van de natuur, met zijn jaargetijden, en was de prooi niet altijd op gezette tijden voorradig. Kortom, perioden van relatieve overvloed aan voedsel wisselde zich af met perioden van schaarste, en warme, droge jaargetijden met natte, vruchtbare perioden. Om toch te kunnen overleven is de mens in staat om in tijden van voedseloverschot - de vette jaren - een energievoorraad aan te leggen, het lichaamsvet. In tijden van voedseltekort kan dit vet in organen en spieren gebruikt worden voor energielevering en daarmee de mens in staat stellen om te overleven. Er is echter één maar: de hersenen zijn voor hun energievoorziening grotendeels aangewezen op bloedsuiker en kunnen geen vetten verbranden. Echter, de suikervoorraad in het lichaam is heel erg klein en het is dan ook belangrijk om in tijden van voedselschaarste zuinig met de suikervoorraad om te gaan. Een oplossing hiervoor is insulineresistentie: dit zorgt ervoor dat onze spieren minder suiker kunnen opnemen, waardoor de kleine voorraad suiker beschikbaar blijft voor de hersenen. Kortom, insulineresistentie is dus een uiterst belangrijk mechanisme om in tijden van voedselschaarste er voor te zorgen dat de hersenen voldoende suiker beschikbaar hebben.

Hoe goed dit mechanisme werkt kunt $u$ zien in figuur 2 uit onderzoek geïnitieerd door Marco Mensink en afgerond door mijn eerste AlO en nu universitair docent Joris Hoeks (2). In dit onderzoek hebben 
wij de insulinegevoeligheid gemeten in volledig gezonde, jonge proefpersonen, zowel in de gevoede situatie als na 60 uur vasten. Zoals $u$ kunt zien ontstaat er na 60 uur vasten een $50 \%$ afname van de insulinegevoeligheid, oftewel er ontstaat sterke insulineresistentie. Deze insulineresistentie is qua omvang te vergelijken met wat we in patiënten met type 2 diabetes mellitus vinden. Dit onderzoek laat zien dat insulineresistentie een belangrijk fysiologisch mechanisme is dat bedoeld is om te kunnen overleven in magere tijden.
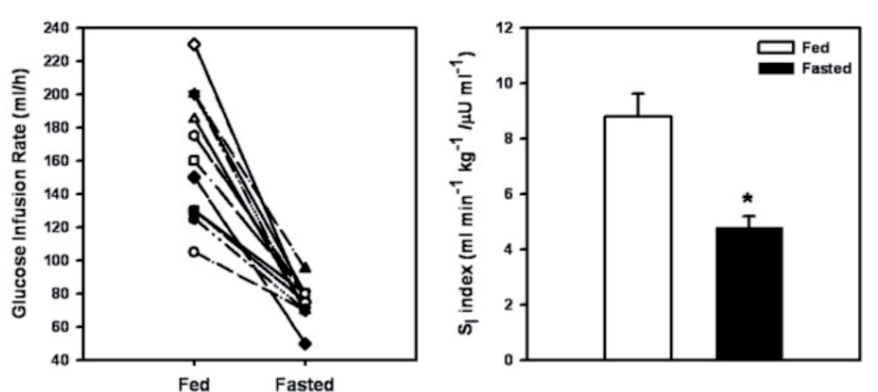

Figuur 2: Het effect van 60 uur vasten op insuline gevoeligheid

Om te begrijpen hoe bovenstaand verhaal iets te maken heeft met type 2 diabetes moeten we ons verdiepen in het mechanisme waarlangs vasten of voedselschaarste tot insulineresistentie kan leiden. In 1963 stelde Sir Philip Randle al dat een verhoogd vetzuuraanbod aan onder andere de spier - zoals bij vasten het geval is - leidt tot een remming van de suikerverbranding. Simpelweg, als er meer vet beschikbaar is voor verbranding in de spier is het niet nodig om ook nog suikers te verbranden (3). Het gevolg hiervan is dat de suikerconcentratie in de spiercel stijgt en dit leidt tot een remming van de suikeropname. Hiermee is de spier dan insulineresistent geworden. Een andere - recentere - theorie, gepostuleerd door Professor Shulman, stelt dat vetten zich stapelen in de spiercel als er een hoog vetzuuraanbod is - zoals tijdens vasten - en dat deze vetstapeling de werking van insuline, en daarmee de opname van suikers in de spier, remt (4). Wat beide theorieën gemeen hebben is dat de insulineresistentie van de spier verklaard wordt uit een overmaat aan vet in de spiercel. Inderdaad zien wij in ons vasten experiment een enorme toename van de hoeveelheid vet in de spiercellen.
Naar we nu weten is deze kennis zeer relevant om te begrijpen hoe type 2 diabetes mellitus - oftewel suikerziekte - ontstaat. Jarenlang heeft men de oorzaak van diabetes gezocht in de stofwisseling - het metabolisme van suikers. Er is onderzocht of er defecten zijn in de receptor voor insuline, in de suikertransporters van de spier, in de capaciteit om suikers op te slaan of te verbranden. Al deze onderzoeken konden echter geen definitief antwoord geven op de vraag hoe diabetes ontstaat. In de afgelopen 20 jaar - mede na publicatie van een baanbrekend overzichtsartikel door Dennis McGarry - is de aandacht verschoven naar het metabolisme van vetten als verklaring voor type 2 diabetes (5). We kunnen dan ook spreken van de vette jaren in het diabetesonderzoek. Net als bij vasten worden bij type 2 diabetes patiënten ook een verhoogd vetgehalte in de spier gevonden. Echter, in tegenstelling tot bij vasten heeft insulineresistentie bij type 2 diabeten geen rol in het beschermen van de suikervoorraad. De type 2 diabeet krijgt namelijk voldoende suikers via de voeding binnen en hoeft dus niet zuinig met de suikervoorraad om te gaan. Sterker nog, de insulineresistentie bij een diabeet zal er toe leiden dat de suikers uit de voeding niet meer opgenomen kunnen worden maar in het bloed blijven circuleren, waardoor de bloedsuikerspiegel stijgt. Op deze wijze leidt insulineresistentie in vette jaren dan ook tot type 2 diabetes.

\section{De relatie tussen obesitas en type 2 diabetes}

Een belangrijke vraag die zich oproept is waarom diabeten zo veel vet in hun spieren stapelen? De laatste paar decennia zijn gekenmerkt door een enorme toename van de welvaart in een aanzienlijk deel van de wereld, we kunnen in dit kader met recht spreken over de vette jaren. De welvaart gaat gepaard met een afname van de fysieke activiteit door een ver doorgevoerde automatisering, maar ook door een alom beschikbaarheid van vaak te vette voeding. Dit alles heeft er in geresulteerd dat de mens gemiddeld steeds zwaarder wordt (6). Tegenwoordig weten we dat overgewicht de belangrijkste risicofactor is voor het ontstaan van type 2 diabetes. Dit wordt sterk geill ustreerd door het feit dat het grote merendeel van de patiënten met type 2 diabetes meer dan $80 \%$ - gekenmerkt wordt door overgewicht.

Reeds in mijn promotieonderzoek heb ik mij gericht op de vraag hoe goed de mens in staat is om de vetverbranding te verhogen als het vetgehalte van de voeding toeneemt. I $\mathrm{k}$ heb toen aangetoond dat de mens zich weliswaar kan aanpassen aan vetrijke voeding, maar dat dit 
een langzaam proces is: de vetverbranding was pas na een week gelijk aan de vetinname, maar in de eerdere dagen leidt een vetrijke voeding tot een netto opslag van vet (7). Helaas is tegenwoordig overal vetrijke of energierijke voeding beschikbaar, en ons lichaam is slecht in staat om signalen af te geven om de voedselinname te beperken. Eigenlijk logisch, want ons lichaam kan niet weten of er na deze 'vette jaren' straks weer 'magere jaren' komen waarin wij onze vetvoorraden nodig zullen hebben. Oftewel, niet alleen vandaag, maar ook morgen en overmorgen hebben wij voldoende te eten, maar het lichaam kan dit niet weten en zal door blijven gaan met het opslaan van vet - zonder dat daar perioden van vasten tegenover staan. Dit vet gaat ook in onze spieren, lever en het hart zitten, en veroorzaakt daar insulineresistentie.

$\mathrm{Nu}$ we weten hoe insulineresistentie en type 2 diabetes ontstaat, lijkt de oplossing ook simpel: we moeten voorkomen dat mensen overgewicht ontwikkelen. Alhoewel ik zeker een voorstander ben van het bestrijden of beter voorkomen van overgewicht, hebben de afgelopen jaren ook aangetoond hoe ontzettend moeilijk dit is. Er zijn allerlei diëten ontwikkeld waarbij bijvoorbeeld alleen koolhydraten of juist alleen vet gegeten mag worden. Soms werken deze diëten goed, maar meestal zijn de effecten toch tijdelijk en worden mensen na verloop van tijd toch weer zwaarder omdat ze weer in hun oude eetpatroon vervallen. Ook de rol van beweging is vaak bestudeerd, maar deze onderzoeken concluderen dat je door extra bewegen maar weinig afvalt (8). Alhoewel deze conclusie waarschijnlijk wetenschappelijk valide is, schuilt er een groot maatschappelijk gevaar in het ongenuanceerd naar buiten brengen van deze conclusie. Het heeft er toe bijgedragen dat de focus in de strijd tegen overgewicht volledig is komen te liggen op de beperking van de voedselinname. Dit is een cruciale fout!

Laten we nog eens kijken naar de prevalentiecijfers van overgewicht en diabetes in Nederland. In 2007 was $46.5 \%$ van de bevolking boven de 18 jaar te zwaar, dat zijn zo'n 6 miljoen Nederlanders. Tegelijkertijd hebben zo'n 1 miljoen mensen diabetes. Kortom, alhoewel er duidelijk een verband is tussen overgewicht en diabetes krijgen gelukkig niet alle mensen met overgewicht ook werkelijk diabetes. In mijn onderzoek richt ik me dan ook op de vraag wat het verschil is tussen obese mensen met en zonder diabetes. Alhoewel ik niet wil pretenderen dat het de enige verklaring is of dat wij de enige zijn die dit vonden, toonde het onderzoek van Vera Schrauwen-Hinderling aan dat beide groepen weliswaar evenveel spiervet hadden, maar dat de type 2 diabeten een verlaagde mitochondriële functie in de beenspier hadden (9). Mitochondria zijn de energiefabriekjes van de cel en verbranden suikers en vetten uit de voeding. Als deze mitochondria minder goed werken dan zal de capaciteit om vetten te verbranden afnemen. Ons onderzoek toont daarmee aan dat het niet de vetopslag in de spier perse is wat tot diabetes leidt, maar vooral ook de balans met de capaciteit om deze vetten te kunnen verbranden (figuur 3).

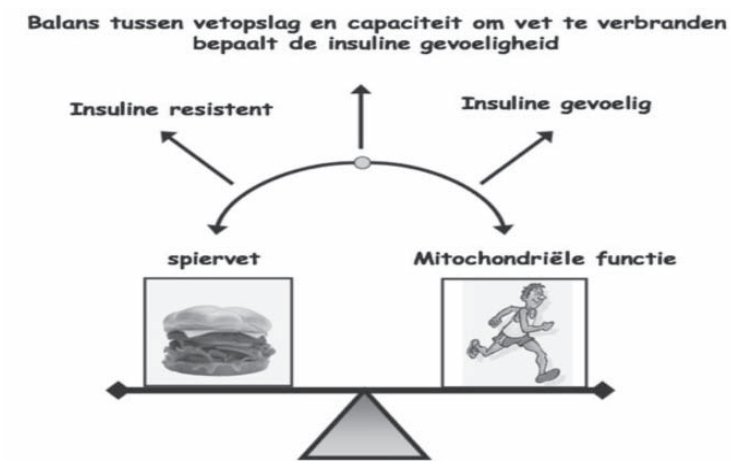

Figuur 3: de balans tussen vetopslag en vetverbrandingscapaciteit bepaalt de insuline gevoeligheid

Ik wil dit graag verder illustreren aan de hand van twee onderzoeksbevindingen. In volwassen ratten zijn wij in staat om in één spier, bijvoorbeeld de rechter poot, een gen tot overexpressie te brengen dat de stapeling van vet stimuleert. Met dit unieke proefdiermodel kunnen wij dus een rat maken die in één poot veel, en in de andere poot weinig vet stapelt. Na opoffering van het dier kunnen we de twee poten vergelijken en direct het effect van de vetstapeling op de insulinegevoeligheid bestuderen. In tegenstelling tot wat verwacht zou worden, was de vette poot niet insulineresistent. Sterker, de insulinegevoeligheid in de vette poot nam juist toe. Opvallend was dat de spier waarin de vetstapeling was verhoogd ook gekenmerkt werd door een verbetering van de mitochondriële functie (10). Een tweede belangrijke bevinding is dat duurtraining zowel bij obese mensen met en zonder type 2 diabetes leidt tot een toename van de hoeveelheid vet in de spieren maar ook een verbetering van de insulinegevoeligheid. Ook nu weer wordt deze toename in vetgehalte van de spier vergezeld door een sterke toename van de mitochondriële functie (11). 
Kortom, deze bevindingen laten zien dat vetopslag in de spier geen ernstige gevolgen hoeft te hebben zolang de vetten maar regelmatig worden gebruikt zoals bij vasten het geval is. Sterker, ook nu geldt weer 'niets is voor niets'. Zo weten we dat voor sporters spiervet juist belangrijk is om langdurende inspanning vol te houden. In dat kader is een review artikel van Bramble \& Lieberman, gepubliceerd in Nature in 2004, erg interessant (12). In dit artikel vroegen de auteurs zich af waarom de mens in de evolutie als soort heeft kunnen overleven. Een arend kan van $1 \mathrm{~km}$ hoogte zijn prooi op de grond zien lopen en een luipaard kan loopsnelheden bereiken tot $120 \mathrm{~km}$ per uur. Hiermee vergeleken heeft de mens als soort maar zeer beperkte fysieke capaciteiten en kan bijvoorbeeld maar beperkt zwemmen en niet vliegen. Hoe kan het dan toch dat de mens kon overleven? Op basis van analyses van het skeletstelsel van verschillende menssoorten gedurende de evolutie concludeerden de auteurs dat de mens een uitzonderlijk goede duursporter is. De mens kan in tegenstelling tot vele andere diersoorten een inspanning enorm lang volhouden. De auteurs veronderstellen dat deze eigenschap zeer belangrijk is geweest om bijvoorbeeld een prooi uit te kunnen putten, maar ook om lange afstanden af te leggen als de omstandigheden daartoe vroegen, bijvoorbeeld om te verhuizen van droge naar vruchtbare gebieden. Alhoewel dit niet onderzocht werd, kan ik mij voorstellen dat om dezelfde reden de capaciteit van de mens om een vetvoorraad op te slaan in de spier, samen met een goed ontwikkelde mitochondriële functie, ook belangrijk is geweest in de overlevingskansen van de menselijke soort.

Laten we nu even terug gaan naar het vliegveld van Brussel. Ik vrees dat velen onder ons niet raar zouden hebben staan kijken van de door de twee Amerikanen gemaakte opmerking. Ook ik zal toegeven dat ik meestal de rolband neem als ik op het vliegveld naar de vertrekhal moet lopen, net zoals we gemakkelijk de roltrap, lift en auto nemen om minimale afstanden te overbruggen en daarmee onze fysieke activiteit minimaliseren. Kortom, fysieke inactiviteit is overal om ons heen, en fysieke activiteit is eerder uitzondering dan regel geworden. Hierdoor zullen wij onze mitochondria en de vetvoorraden in de spier niet of nauwelijks nog aanspreken. Juist onder deze omstandigheden kan de vetopslag schadelijk worden en leiden tot insulineresistentie en uiteindelijk diabetes.
Deze voorbeelden onderschrijven de noodzaak om fysieke activiteit te propageren ter bestrijding van type 2 diabetes, zelfs als fysieke activiteit niet of nauwelijks bijdraagt aan gewichtsverlies. Gelukkig wordt deze visie tegenwoordig steeds meer onderstreept, en weten we nu dat "bewegen de beste manier is om diabetes te voorkomen". Ik ben er dan ook van overtuigd dat de komende jaren onderzoek naar de manieren om mensen aan het bewegen te krijgen steeds belangrijker zal worden, en wat mij betreft begint dit bij het verder stimuleren van bewegingsonderwijs bij de jeugd, zodat zij ervaren dat bewegen niet alleen gezond maar vooral ook heel leuk is.

\section{Diabetes: eigen schuld, dikke bult?}

Een verkeerde conclusie die uit bovenstaand verhaal getrokken zou kunnen worden is dat type 2 diabeten minder actief zijn dan mensen met overgewicht die geen diabetes ontwikkelen en het dus hun eigen schuld is dat ze diabetes krijgen. Alhoewel ons onderzoek laat zien dat zowel mensen met en zonder diabetes erg gebaat zijn bij het volgen van een trainingsprogramma, is er geen aanwijzing dat de type 2 diabetes patiënten bij aanvang al minder actief waren. Sterker, in ons onderzoek includeren wij met regelmaat type 2 diabetes patiënten die behoorlijk fysiek actief zijn en bijvoorbeeld regelmatig lange wandelingen door het mooie Limburgse landschap maken. Toch vinden we ook bij deze type 2 diabeten dat de mitochondria minder goed functioneren dan bij mensen met evenveel overgewicht, maar zonder diabetes. De reden hiervoor is nog onbekend. In 2004 heb ik een hypothese geformuleerd waarbij ik suggereer dat het mogelijk zo is dat de vetten die zich in de spier stapelen schade kunnen toebrengen aan de mitochondria (13).

Naast energie maken mitochondria ook zogenaamde radicalen aan. Radicalen zijn stoffen, die in het lichaam door reacties met zuurstof ontstaan en beschadigingen kunnen veroorzaken aan allerlei structuren. Mogelijk kent $u$ de radicalen het best van de reclame, want daarin wordt vaak genoemd dat radicalen de reden zijn voor de rimpels die bij veroudering ontstaan, en dat door het smeren van crèmes met antioxidanten deze rimpelvorming kan worden voorkomen. Ik zal mij hier niet uitlaten over de effectiviteit van deze middeltjes, maar wat ik wel geloof is dat radicalen inderdaad schade kunnen toebrengen aan moleculaire structuren en daarmee een rol kunnen spelen bij veroudering en het ontstaan van mitochondriële dysfunctie. Zo is het inderdaad bekend dat de mitochondriële functie bij oudere mensen verminderd is ten opzichte van jongere mensen (14), dat is waarschijnlijk 
ook de reden waarom Lance Armstrong tot zijn 35e nog de Tour de France kon winnen, maar na zijn comeback op 39-jarige leeftijd toch een stapje terug moest doen en de jongere generatie voor moest laten gaan.

De vraag waar ik mij de komende jaren mee bezig zal houden is hoe de mitochondria zich zelf beschermen tegen de beschadiging door radicalen? Een kandidaat hiervoor is mitochondriële ontkoppeling en hierbij spelen ontkoppelingseiwitten mogelijk een rol (15). Verbranding van vet en suiker in de mitochondria leidt tot de vorming van een ladingsverschil over de binnenste membraan van dit organel. $U$ kunt dit vergelijken met een batterij, met een plus- en een minkant. Als dit ladingsverschil groot genoeg is, gaat er een stroom van geladen deeltjes lopen door een bepaald eiwitcomplex - het ATPase. Deze stroom van lading door het ATPase wordt gebruikt om energie te maken, net zoals de stroom uit een batterij een lamp kan doen branden of een radio kan doen spelen. Soms is er echter kortsluiting, en kan de lading via andere routes weglekken. In de mitochondria heet dit proces ontkoppeling: de lading stroomt dan via andere eiwitten weg en niet via het ATPase, en er wordt geen energie gemaakt.

Deze kortsluiting verstoort dus de energieproductie en lijkt daarmee dus een nutteloos proces. Toch is dat niet het geval: het blijkt dat de mate van radicaalvorming afhankelijk is van het ladingsverschil over de binnenste mitochondriële membraan. Als de snelheid waarmee vetten en koolhydraten worden verbrand hoger is dan de snelheid waarmee de lading terug kan stromen door het ATPase wordt het ladingsverschil te groot en zal een deel van de lading reageren met zuurstofmoleculen en daarbij zuurstofradicalen vormen. Een manier om dit te voorkomen is ontkoppeling, waarbij het overschot aan lading via andere eiwitten kan wegstromen. Kortom, ontkoppeling is nuttig omdat het zorgt dat de mitochondria minder radicalen vormen. Nu weten we al enige tijd dat type 2 diabeten minder van het ontkoppelingseiwit UCP3 in de spier hebben (16). In de komende jaren wil ik dan ook via het door NWO gefinancierde $\mathrm{VICl}$ project gaan onderzoeken of de radicaalproductie vermeerderd en ontkoppeling verminderd is in diabeten en of dat de reden is waarom de mitochondriële functie verlaagd is bij deze patiënten.

\section{Cellulaire insulineresistentie}

Ik wil nu weer even met u teruggaan naar de vetstapeling in de spier, en hoe dit tot insulineresistentie kan leiden. Het baanbrekende onderzoek van Professor Shulman van de Yale University heeft aangetoond dat zogenaamde vetzuurintermediairen hierbij een belangrijke rol spelen
(4). Vetzuurintermediairen zijn producten die ontstaan als vetten triglyceriden - worden afgebroken tot vetzuren. Vooral het product diacylglycerol is naar voren geschoven als de boosdoener in het ontstaan van insulineresistentie. Professor Shulman heeft hiertoe een indrukwekkend aantal onderzoeken gepubliceerd, één voor één in absolute top wetenschappelijke tijdschriften, en deze hypothese is de afgelopen 15 jaar leidend geweest in het onderzoeksveld. Alhoewel ik volledig onderschrijf dat dit werk van groot belang is geweest voor de ontwikkeling van het onderzoeksveld, is er ook een keerzijde van de medaille. Het is de afgelopen jaren lastig gebleken om reviewers en editors te overtuigen van bevindingen die niet in lijn zijn met de diacylglycerol hypothese waardoor het zelfs kan gebeuren dat 'negatieve' bevindingen niet, of in tijdschriften met een lagere impact factor gepubliceerd worden. Deze publicatiebias zie ik als een enorme bedreiging voor de voortgang van wetenschappelijk onderzoek. De diacylglycerol hypothese heeft ons 'blind' gemaakt voor alternatieve verklaringen en daardoor staan we nu eigenlijk nog maar aan het begin van onze kennis over het exacte cellulaire mechanisme waarlangs vetstapeling tot insulineresistentie kan leiden. Zo laat recent onderzoek uit onze maar ook andere onderzoeksgroepen zien dat een stapeling van diacylglycerol in de spier niet per se tot insulineresistentie hoeft te leiden, en dat de diacylglycerol hypothese mogelijk te simpel is en niet volledig generaliseerbaar $(10 ; 17 ; 18)$. In mijn leerstoel zal ik mij dan ook blijven richten op de vraag hoe vetstapeling in de spier kan leiden tot insulineresistentie van de spiercel, en me daarbij niet laten afleiden door heersende dogma's. Zo toont onze recente data aan dat de Randle cycle in sommige gevallen een goede verklaring is voor het ontstaan van insulineresistentie, en dat dit mechanisme ten onrechte in de vergetelheid is geraakt.

\section{Vetstapeling in andere weefsels}

Tot nu toe heb ik het gehad over hoe vetstapeling in de spier kan bijdragen aan het ontstaan van type 2 diabetes mellitus. In recente jaren wordt het echter steeds duidelijker dat ook vervetting van de lever en het hart kunnen leiden tot metabole verstoringen. Dit wordt mooi geïllustreerd in de documentaire 'super size me'. In deze documentaire doet Morgan Spurlock verslag van een experiment met zichzelf in de hoofdrol. Hij besluit om gedurende 30 dagen alleen nog te eten bij een bekende fastfoodketen, en elke keer als de bediening vraagt of hij zijn bestelling wil 'super sizen' hierop positief te antwoorden. Het resultaat is dat hij na 30 dagen $11.1 \mathrm{~kg}$ in gewicht is toegenomen, zijn cholesterol 
en bloedsuikergehalte sterk is gestegen en hij een vette lever heeft ontwikkeld.

Uit onderzoek verricht in 2004 in de staat Dallas van de Verenigde Staten bleek dat ongeveer $1 / 3$ van de volwassen populatie gekenmerkt werd door een vette lever (19). Zeer recent is aangetoond dat personen met een vette lever een $5 x$ hoger risico hebben om diabetes te ontwikkelen (20). Een vette lever heeft echter nog meer gevolgen: het leidt tot een verstoring in het triglyceride en cholesterol metabolisme en vormt daarmee ook een risicofactor voor het ontstaan van hart- en vaatziekten. In onderzoek gefinancierd door het Diabetes Fonds zal ik de komende jaren onderzoeken of bewegen ook een positief effect heeft op de vervetting van de lever, en daarmee mogelijk kan verklaren waarom beweging zo veel gezondheidseffecten heeft.

Ook vervetting van de hartspier kan bijdragen aan het ontstaan van harten vaatziekten (21). Recentelijk hebben we laten zien dat circulerende vetzuren een belangrijke rol spelen bij het ontstaan van hartvervetting, en dat duurtraining de hoeveelheid vet in het hart kan doen verlagen (22). Mogelijk biedt dit onderzoek meer inzicht in de mechanismen waarlangs voeding en beweging een rol kan spelen bij het voorkomen van diabetesgerelateerde hart- en vaatziekten.

Ik hoop met deze voorbeelden $\mathrm{u}$ duidelijk te hebben gemaakt dat niet alleen vetstapeling in de spier, maar ook in de lever en het hart een groot probleem vormt voor type 2 diabetes patiënten (figuur 4). In de komende jaren zal ik mij richten op de vraag hoe deze vetstapeling in type 2 diabetes patiënten tot gezondheidsproblemen leidt, maar ook op de vraag hoe deze vetstapeling nu eigenlijk ontstaat en hoe het voorkomen kan worden.

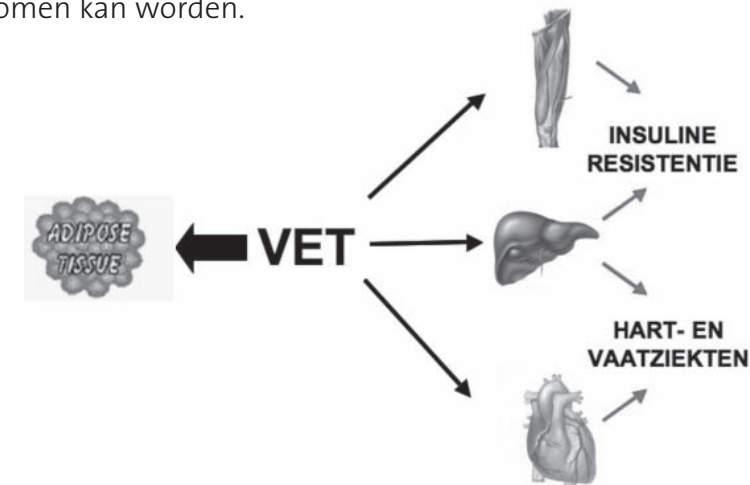

Figuur 4: vetstapeling in spier, lever en hart als oorzaak van insuline resistentie en diabetesgerelateerde hart-en vaatziekten
Maar hoe doen we dit onderzoek eigenlijk? Een van de uitgangspunten in mijn onderzoek is dat om te begrijpen hoe diabetes ontstaat bij de mens, je ook onderzoek moet doen aan de mens. Dit betekent niet dat ik geen waarde hecht aan onderzoek in proefdier of celmodellen: het is evident dat proefdier- en celonderzoek noodzakelijk zijn om meer kennis op te doen over de mechanismen die tot diabetes kunnen leiden. Het uitgangspunt blijft echter de mens. Onderzoek naar de spierstofwisseling is bij de mens goed mogelijk. Hiertoe maken we gebruik van zogenaamde spierbiopten. Met enige zelfspot kan ik u melden dat dit een relatief eenvoudige ingreep is: onder locale verdoving wordt een kleine incisie gemaakt in de huid, waarna er via een holle naald een kleine hoeveelheid spierweefsel wordt afgenomen. Met steeds geavanceerdere technieken kan dit spierweefsel vervolgens nader worden onderzocht, bijvoorbeeld op mitochondriële functie (figuur 5).
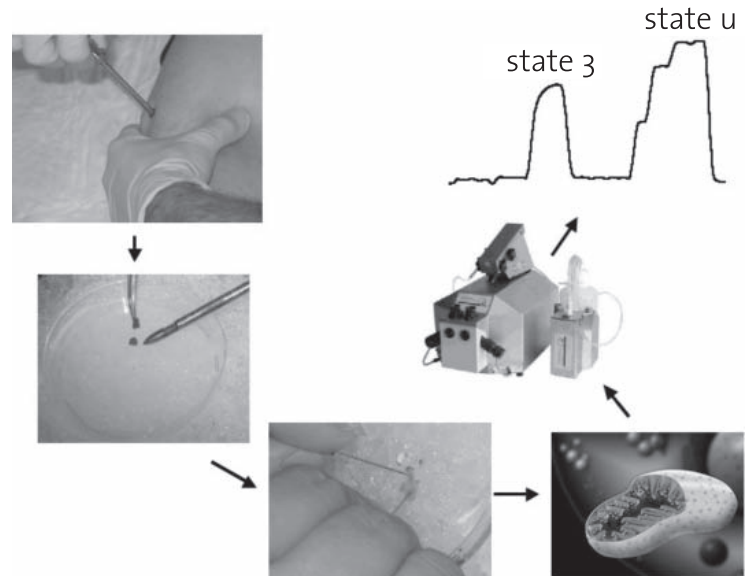

Figuur 5: het meten van mitochondrïle functie in skeletspierbiopten middels hoge resolutie respirometrie

Lastiger wordt het als we ook onderzoek willen doen naar de lever of de hartspier. Afgezien van chirurgische ingrepen is het niet mogelijk om deze weefsels bij relatief gezonde proefpersonen af te nemen. Om deze weefsels toch te kunnen bestuderen zijn daarom beeldvormingstechnieken nodig die op niet-invasieve wijze de vetstapeling en energiestofwisseling in lever en hart in beeld kunnen brengen. Een belangrijke mijlpaal in mijn onderzoek is dan ook de samenwerking met de afdeling Radiologie, welke ik in 2000 ben gestart 
met Dr. Eline Kooi. Al snel werd deze samenwerking uitgebreid via het onderzoek van Vera Hinderling, en richtte zich op het metabolisme van spier, lever en hartspier (figuur 6). Op dit moment is de samenwerking uitgegroeid tot een groot team van wetenschappers en samen met Professor Joachim Wildberger hoop ik deze samenwerking de komende jaren verder uit te breiden en een stevige structurele basis te kunnen geven. Steeds nieuwere methodieken en verfijndere analyses maken het mogelijk om nog kleinere substraten op te sporen en ook om deze in de tijd te volgen. Zo zullen we op zeer korte termijn 13C-magnetische resonantie spectroscopie toe gaan passen in het humane onderzoek in Maastricht, waardoor het zelfs mogelijk wordt om exact te volgen of de vetten uit onze voeding uiteindelijk in de lever of spier terechtkomen, en daarmee bijdragen aan het ontstaan van vervetting van deze weefsels (23).

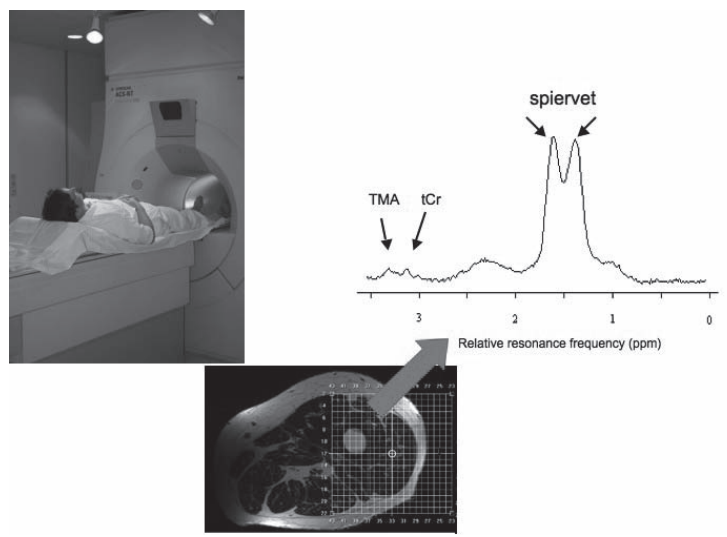

Figuur 6: het analyseren van spiervet middels magnetische resonantie spectroscopie

\section{Vette jaren van het onderzoek}

Ik hoop $u$ in de afgelopen minuten duidelijk te hebben gemaakt dat het diabetesonderzoek in zijn vette jaren zit. Ik hoop ook dat ik heb duidelijk kunnen maken dat we in de afgelopen jaar veel meer te weten zijn gekomen over de factoren die tot type 2 diabetes leiden, maar dat er ook nog veel vraagtekens zijn. Dit betekent dat er veel geld voor wetenschappelijk onderzoek nodig blijft. Mijn hoop is dan ook dat de huidige en toekomstige regeringspartijen het belang van een sterke kenniseconomie - ook in tijden van economische crisis blijven onderkennen en de onderzoeksfinanciering geen magere jaren tegemoet gaat. Daarbij spreek ik de hoop uit dat beleidsmakers van universiteiten en Nederlandse subsidiegevers blijven investeren in jonge onderzoekers met innovatieve ideeën en consistente prestaties, en maatschappelijke- en klinische impact in beschouwing nemen bij het beoordelen van onderzoeksprestaties. Daarbij moet voorzichtigheid betracht worden bij het verheffen van de impactfactor tot het hoogste goed. Er zijn voldoende voorbeelden van publicaties in hoge impact tijdschriften, die in feite een negatieve impact hebben op de voortgang van het onderzoek. Ik wil deze gewaagde uitspraak illustreren aan de hand van één voorbeeld. Zoals eerder gemeld zijn mitochondria essentieel voor het leven omdat ze uit suikers en vetten energie maken die nodig zijn voor vitale processen in het lichaam. Toch kan een cel ook zonder tussenkomst van mitochondria energie uit suikers halen, maar dit proces is erg inefficiënt en normaal gesproken niet toereikend om alle benodigde energie te produceren. Laten we nu een experiment doen waarbij de mitochondria defect worden gemaakt: wat zal de cel in deze situatie doen? Er is maar een optie: de cel zal suikers afbreken om energie te produceren en de cel moet in feite heel veel suikers afbreken omdat de energielevering heel inefficiënt is. Bewijst dit experiment nu dat je als diabetespatiënt beter maar geen of slechte mitochondria kunt hebben, zodat je veel suikers gaat metaboliseren? Mijn antwoord is nee! Het experiment is uit een fysiologische context gehaald en we weten heel goed dat patiënten met mitochondriële aandoeningen grote gezondheidsproblemen ontwikkelen. Toch is dit een voorbeeld van een onderzoek dat in 2007 in een van de belangrijkste tijdschriften werd gepubliceerd (24), en vervolgens veelvuldig geciteerd als bewijs dat mitochondria geen rol spelen in de etiologie van type 2 diabetes. Wat mij betreft toont dit voorbeeld aan dat in de wetenschap - net als in de hedendaagse politiek - het ongenuanceerd brengen van een gewaagde boodschap goed scoort. Maar deze strategie leidt maar zelden tot echte oplossingen. Dit type onderzoek brengt ons geen stap dichter bij de belangrijke vraag of mitochondriële functie nu wel of niet belangrijk is bij het ontstaan van diabetes bij de mens. Ik besef dat de impactfactor een belangrijk instrument is in de wetenschap en gelukkig zijn er ook veel positieve voorbeelden te noemen. Toch bepleit ik dat tijdschriften niet alleen oog hebben voor elegante moleculair biologische experimenten, maar ook maatschappelijke of klinische relevantie in hun beoordeling meenemen. 
De onderzoeksfinanciering van de afgelopen jaren heeft mij in ieder geval in staat gesteld een onderzoeksteam op te bouwen waarin een combinatie van verschillende expertises is gebundeld. Dit maakt het mogelijk om translationeel onderzoek te verrichten waarbij we de kennis uit cel- en proefdierwerk onmiddellijk kunnen vertalen en vergelijken met de bevindingen die wij bij de mens doen. Zeer belangrijk hierbij is dat het onderzoeksteam functioneert als een hecht geheel. Ik ben dan ook dankbaar dat er in mijn onderzoeksteam een sterk 'hand in hand, kameraden' mentaliteit is gegroeid, wat ik als trouw Feyenoord supporter steeds heb nagestreefd. Ik ben ook blij te zien dat de samenwerking zich de afgelopen jaren steeds verder uitbreidt, met een verdere bundeling van het metabole diabetes onderzoek binnen de universiteit Maastricht, maar ook met nieuwe Nederlandse maar ook buitenlands initiatieven zoals de samenwerking met het German Diabetes Center onder leiding van Professor Michael Roden in Düsseldorf. Ik ben ervan overtuigd dat deze samenwerkingen op termijn een synergistisch effect zullen hebben op de onderzoeksresultaten. Belangrijker nog, samenwerking is noodzakelijk om sneller te komen tot een echte oplossing voor deze vervelende ziekte. Samenwerking is echter ook lastig. Een maximum aan de grootte van een promotieteam en het belang van $1^{\mathrm{e}}, 2^{\mathrm{e}}$ of laatste auteurschappen maakt het soms onaantrekkelijk om een samenwerking aan te gaan. Het is dan ook in toenemende mate belangrijk om na te denken hoe deze drempels weggenomen kunnen worden. Samenwerking vergt echter meer dan het wegnemen van de drempels en het bij elkaar brengen van de goede spelers. Het vergt ook het kweken van een gezamenlijk verantwoordelijkheidsgevoel en de wil om gezamenlijk voor een doel te vechten. Ik zie hier een mooie taak neergelegd voor de nieuwe decaan van de Faculty of Health, Medicine and Life Sciences en zou graag de heer Van Marwijk voordragen als kandidaat voor deze functie. Bert van Marwijk, recent benoemd tot 'Limburger van verdienste', is bij uitstek in staat om van een groep met goede spelers ook een top team te maken. Kortom, de ideale man voor de Universiteit Maastricht. Mocht het college mijn suggestie echter overnemen, dan wel op 1 voorwaarde: het moet hier slechts om een parttime aanstelling gaan. Mijn zoon is nu bijna 8 en dus oud genoeg om over 30 jaar nog de verloren finale van 2010 te herinneren. Het college van bestuur zal zich dus moeten beseffen dat we niet nog een generatie kunnen opzadelen met een voetbaltrauma, en dus moet Bert van Marwijk in staat worden gesteld om eerst in 2014 de cup voor Nederland te pakken.

\section{Dankwoord}

Mijnheer de rector, dames en heren,

Ik hoop dat ik $u$ geen zoete praatjes heb staan verkopen maar u duidelijk heb kunnen maken dat een zoete ziekte zijn oorsprong vindt in de vette jaren. Daarmee kom ik aan het einde van mijn rede, en daarmee bij het belangrijkste onderdeel, het dankwoord. Het is ook het gevaarlijkste onderdeel, omdat je met zekerheid weet dat je altijd mensen tekort doet. Daarom, iedereen die een bijdrage heeft geleverd aan al het mooie werk wat we de afgelopen jaren hebben kunnen doen: hartelijk dank!

Toch wil ik ook een aantal mensen bij naam benoemen. Allereerst wil ik de Faculty of Health, Medicine and Life Sciences en de Stichting Wetenschapsbeoefening UM bedanken voor de instelling van deze bijzondere leerstoel en het in mij gestelde vertrouwen. Ook alle medewerkers van de vakgroep Humane Biologie en van het NUTRIM beheersbureau dank ik hartelijk voor de onaflatende steun. Professor Ronald Mensink en Professor Annemie Schols wil ik nadrukkelijk bedanken voor de steun en het vertrouwen, met name in de meer recentere jaren van mijn carrière, wat uiteindelijk geleid heeft tot deze voordracht.

Mijn bewandeling van het pad dat wetenschappelijk onderzoek heet begon in 1993 met mijn stage bij Professor Marleen van Baak, van wie ik de eerste kneepjes van het vak leerde. Nog steeds denk ik met veel plezier terug aan mijn stageonderzoek, wat ook vandaag de dag nog steeds een uitdagend onderzoeksproject zou zijn. In augustus 1994 ben ik vervolgens gestart met mijn promotieonderzoek bij Professor Klaas Westerterp, Professor Wim Saris en Dr. Wouter van Marken Lichtenbelt. Ik ben nog steeds dankbaar dat jullie het aan hebben gedurfd om met dat stille manneke in zee te gaan en dat ik mijn promotieonderzoek bij jullie mocht verrichten. Het is een zeer goede basis geweest voor mijn verdere carrière.

Wouter, als mijn co-promotor en dagelijkse begeleider heb ik zeer veel aan jou te danken. De vele zinnige en soms onzinnige discussies hebben er voor gezorgd dat ik mijn promotieonderzoek als zeer plezierig herinner. Jouw kwaliteit om serieus te zijn wanneer noodzakelijk, te relativeren wanneer gewenst en te steunen wanneer nodig maken dat 
ik nog steeds oprecht meen dat ik me geen betere co-promotor had kunnen voorstellen. Ik ben zeer blij en trots dat het jou de laatste jaren wetenschappelijk ook voor de wind gaat, en ben dankbaar dat ik nog steeds bijna dagelijks met je mag samenwerken en nog steeds veel van je kan leren.

Tijdens mijn AlO periode heb ik 8 maanden doorgebracht in het National Institute of Health, in Phoenix in de Verenigde Staten. Ik heb daar mijn eerste lessen gekregen in de moleculaire biologie onder supervisie van de Zwitserse Amerikaan, of Amerikaanse Zwitser Eric Ravussin. Alhoewel Eric er vandaag niet bij is, wil ik hem graag bedanken. Eric heeft me laten zien hoe inspirerend het is om in een hecht team te werken en trots te mogen zijn op behaalde resultaten, aspecten die ik vandaag de dag nog steeds in mijn eigen onderzoeksteam probeer te incorporeren. Bovenal is Eric een warm persoon en een goede vriend en kan ik moeiteloos van hem verdragen dat hij me steevast TinTin noemt.

Na mijn promotie in 1998 ben ik een nieuw project begonnen wat tot op vandaag in de boeken staat als SHOCk. De samenwerking met Professor Hesselink is een hele vruchtbare gebleken. Beste Matthijs, het is natuurlijk onmogelijk met woorden te beschrijven hoeveel meerwaarde onze samenwerking heeft opgeleverd. Klein begonnen als onderzoeksteam met Gert Schaart, Joris Hoeks en Esther MoonenKornips hebben we inmiddels een hele mooie SHOCk groep opgebouwd. Kern in deze samenwerking is het onvoorwaardelijke vertrouwen en een gelijke filosofie over hoe wetenschap bedreven zou moeten worden. Ook buiten het werk is er gelukkig meestal voldoende tijd om elkaar te treffen, met name op de tochtjes op de racefiets door het mooie Limburgse land. En ondanks al onze gezamenlijke onderzoeken zijn we er nog steeds niet achter hoe het toch kan dat de heuvels in Limburg steeds steiler en hoger worden. Ik ben erg blij dat ik over 2 weken naar jouw rede mag luisteren en hoop dat we de samenwerking nog lang mogen doorzetten.

Veel dank gaat uiteraard naar de mensen die het echte werk doen, in het bijzonder de zojuist al genoemde SHOCk groep. Alle AIO's, post-docs en analisten van nu en het verleden, die ontelbare spierbiopten hebben genomen, ORO's hebben gekleurd of MRS scans hebben uitgevoerd. Zonder jullie inzet zou alles onmogelijk zijn geweest. Ik prijs me oprecht gelukkig dat ik het voorrecht heb om met zulke talentvolle onderzoekers te hebben mogen werken en hoop te mogen blijven werken in de toekomst.
Last, but not least, mijn familie. Pa en ma, schoonouders, broer, zus en overige familieleden. Jullie weten dat ik er niet van hou om in de schijnwerpers te staan en dat ik liever met jullie over wielrennen of andere belangrijke zaken praat dan over het werk. Bij jullie kan ik altijd gewoon volledig mezelf zijn en dat is van onschatbare waarde.

Lieve Max, Sara en Amber: hoeveel geluk kun je als papa hebben? Jullie maken elke dag tot een feest met de kleine dingen die het leven echt de moeite waard maken. 'Papa, is het vandaag morgen?' of 'Je raadt nooit wat ik op de crèche gegeten heb: het begint met 'knakworst', dit soort uitspraken doen alle problemen vergeten. Ik ben erg blij dat ik zo veel van jullie mag leren en vind het heerlijk dat jullie er vandaag bij zijn!

Lieve Vera, de dag dat jij mijn leven in liep is absoluut de mooiste dag van mijn leven! Jij bezorgt mij, en Max, Sara en Amber zoveel vreugde in het leven, en jouw liefde zorgt er voor dat ik niet uit het oog kan verliezen waar het werkelijk om draait in het leven. En ook al geniet ik enorm van het samenwerken met jou, echt genieten doen we in onze vrije tijd, in het vlakke Limburgse heuvelland en soms - maar helaas te weinig - in de mooie Zwitserse bergen van jouw geliefde vaderland. Dank voor je steun en ik hoop dat we samen nog vele vette jaren voor ons hebben.

Ik heb gezegd. 


\section{Referenties}

1. IDF Diabetes Atlas 4th edn. In International Diabetes Federation, 2009

2. Hoeks J, van Herpen NA, Mensink M, Moonen-Kornips E, van Beurden D, Hesselink MK, Schrauwen P: Prolonged fasting identifies skeletal muscle mitochondrial dysfunction as consequence rather than cause of human insulin resistance. Diabetes 59:2117-2125, 2010

3. Randle PJ, Garland PB, Hales CN, Newsholme EA: The glucose-fatty acid cycle: Its role in insulin sensitivity and the metabolic disturbances of diabetes mellitus. Lancet i:785-789, 1963

4. Shulman Gl: Cellular mechanisms of insulin resistance. J Clin Invest 106:171176,2000

5. McGarry JD: What if Minkowski had been ageusic? An alternative angle on diabetes. Science 258:766-770, 1992

6. Finucane MM, Stevens GA, Cowan MJ, Danaei G, Lin JK, Paciorek CJ, Singh GM, Gutierrez HR, Lu Y, Bahalim AN, Farzadfar F, Riley LM, Ezzati M: National, regional, and global trends in body-mass index since 1980: systematic analysis of health examination surveys and epidemiological studies with 960 countryyears and 9.1 million participants. Lancet 377:557-567, 2011

7. Schrauwen P, van Marken Lichtenbelt WD, Saris WH, Westerterp KR: Changes in fat oxidation in response to a high-fat diet. Am J Clin Nutr 66:276-282, 1997

8. Swinburn B, Sacks G, Ravussin E: Increased food energy supply is more than sufficient to explain the US epidemic of obesity. Am J Clin Nutr 90:1453-1456, 2009

9. Schrauwen-Hinderling VB, Kooi ME, Hesselink MK, Jeneson JA, Backes WH, van Echteld CJ, van Engelshoven JM, Mensink M, Schrauwen P: Impaired in vivo mitochondrial function but similar intramyocellular lipid content in patients with type 2 diabetes mellitus and BMI-matched control subjects. Diabetologia 50:113-120, 2007

10. Timmers S, de Vogel-van den Bosch J, Hesselink MK, van Beurden D, Schaart C, Ferraz MJ, Losen M, Martinez-Martinez P, De Baets MH, Aerts JM, Schrauwen P: Paradoxical increase in TAG and DAG content parallel the insulin sensitizing effect of unilateral DGAT1 overexpression in rat skeletal muscle. PLoS One 6:e14503, 2011

11. Meex RC, Schrauwen-Hinderling VB, Moonen-Kornips E, Schaart G, Mensink $M$, Phielix E, van de Weijer T, Sels JP. Schrauwen P. Hesselink MK. Restoration of muscle mitochondrial function and metabolic flexibility in type 2 diabetes by exercise training is paralleled by increased myocellular fat storage and improved insulin sensitivity. Diabetes 59:572-579, 2010

12. Bramble DM, Lieberman DE: Endurance running and the evolution of Homo. Nature 432:345-352, 2004

13. Schrauwen P, Hesselink MK: Oxidative capacity, lipotoxicity, and mitochondrial damage in type 2 diabetes. Diabetes 53:1412-1417, 2004

14. Petersen KF, Befroy D, Dufour S, Dziura J, Ariyan C, Rothman DL, DiPietro L, Cline GW, Shulman GI: Mitochondrial dysfunction in the elderly: possible role in insulin resistance. Science 300:1140-1142, 2003
15. Brand MD, Affourtit C, Esteves TC, Green K, Lambert AJ, Miwa S, Pakay JL, Parker $\mathrm{N}$ : Mitochondrial superoxide: production, biological effects, and activation of uncoupling proteins. Free Radic Biol Med 37:755-767, 2004

16. Schrauwen P. Hesselink MK, Blaak EE, Borghouts LB, Schaart G, Saris WH, Keizer HA: Uncoupling protein 3 content is decreased in skeletal muscle of patients with type 2 diabetes. Diabetes 50:2870-2873, 2001

17. Dube JJ, Amati F, Toledo FG, Stefanovic-Racic M, Rossi A, Coen P, Goodpaster BH: Effects of weight loss and exercise on insulin resistance, and intramyocellular triacylglycerol, diacylglycerol and ceramide. Diabetologia, 2011

18. Jocken JW, Moro C, Goossens GH, Hansen D, Mairal A, Hesselink MK, Langin D, van Loon LJ, Blaak EE: Skeletal muscle lipase content and activity in obesity and type 2 diabetes. J Clin Endocrinol Metab 95:5449-5453, 2010

19. Szczepaniak LS, Nurenberg P, Leonard D, Browning JD, Reingold JS, Grundy S, Hobbs HH, Dobbins RL: Magnetic resonance spectroscopy to measure hepatic triglyceride content: prevalence of hepatic steatosis in the general population. Am J Physiol Endocrinol Metab 288:E462-468, 2005

20. Sung KC, Kim SH: Interrelationship between Fatty Liver and Insulin Resistance in the Development of Type 2 Diabetes. J Clin Endocrinol Metab 96: 1093-1097, 2011

21. McGavock JM, Victor RG, Unger RH, Szczepaniak LS: Adiposity of the heart, revisited. Ann Intern Med 144:517-524, 2006

22. Schrauwen-Hinderling VB, Hesselink MK, Meex R, van der Made S, Schar M, Lamb H, Wildberger JE, Glatz J, Snoep G, Kooi ME, Schrauwen P: Improved ejection fraction after exercise training in obesity is accompanied by reduced cardiac lipid content. J Clin Endocrinol Metab 95:1932-1938, 2010

23. Ravikumar B, Carey PE, Snaar JE, Deelchand DK, Cook DB, Neely RD, English PT, Firbank MJ, Morris PG, Taylor R. Real-time assessment of postprandial fat storage in liver and skeletal muscle in health and type 2 diabetes. Am J Physiol Endocrinol Metab 288:E789-797, 2005

24. Pospisilik JA, Knauf C, Joza N, Benit P, Orthofer M, Cani PD, Ebersberger I, Nakashima T, Sarao R, Neely G, Esterbauer H, Kozlov A, Kahn CR, Kroemer G, Rustin P, Burcelin R, Penninger JM: Targeted deletion of AlF decreases mitochondrial oxidative phosphorylation and protects from obesity and diabetes. Cell 131:476-491, 2007 
